\title{
GUIDELINES ON EVALUATING PASSENGER EVACUATION POSSIBILITIES IN AVIATION INCIDENTS INVOLVING FIRES
}

\author{
Irina LAZAREVA ${ }^{1}$, Vladimir SHESTAKOV ${ }^{2}$ \\ Aviation Institute of Riga Technical University, Lomonosova St. 1, Riga, LV 1019, Latvia \\ E-mail: 1lira112@inbox.lv (corresponding author); ${ }^{2}$ shestakov@inbox.lv
}

Received 2014 June 19; accepted 17 March 2016

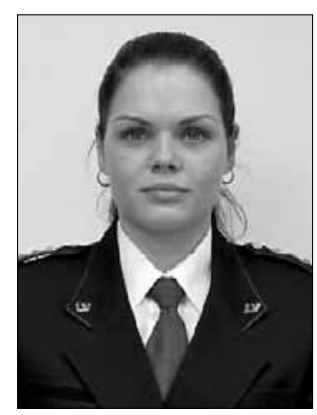

Irina Lazareva, was born in 1986 in Riga.

Education: Fire Safety and Civil Protection College of Riga Technical University (RTU),

Technician (2007); Fire Safety and Civil Defence College of RTU, Engineer (2009);

Institute of Aeronautics, Faculty of Transport and Mechanical Engineering, Riga Technical

University, Master's Degree in Aviation Transport and Qualification of Mechanical

Engineer of Aircraft Technical Maintenance (2012).

Affiliations and functions: Doctoral Student and Assistant at the Aircraft Maintenance

Division, Institute of Aeronautics, Riga Technical University.

Research interests: aircraft landings with crosswinds, aircraft dynamic characterized parameter evaluation, ensuring of flight safety in the airports.

Publications: author of 2 publications

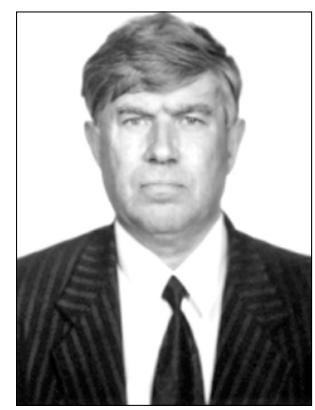

Vladimir SHESTAKOV, was born in 1938 in Voronezh region, Russia.

He graduated from Riga Institute of Civil Aviation Engineers in 1963 in Technical Aircraft and Engines exploitation. Professor, Doctor of Engineering Sciences (Dr Habil Sci. Eng.). Education: Riga Civil Aviation Engineering Institute, Mechanical Engineer (1963), Doctoral Degree in Aviation Leningrad Civil Aviation Academy (1984), Doctor Habilitus Degree in Engineering (1992), Full Member of International Academy of Ecology and Safety of Vital Functions (1994).

Affiliations and functions: Head of the Aircraft Maintenance Division, Riga Technical University, Aviation Institute.

Research interests: fields of professional air transport exploitation, flights safety, ecology and life protection sciences, ecologically pure non-traditional kinds of transport. Publications: author of 245 published works, 25 teaching and methodical books, 9 certificates of inventions, 3 textbooks (in co-authorship) and 2 monographs.

\begin{abstract}
Accident analysis of survived people shows that the main causes of fire death are the hazardous effects and consequences of panic attacks which usually occur in such situations. The passengers are killed by heat and toxicity of combustion products. This depends on the materials used in an aircraft's construction, especially for interior decoration. The time available for the survival of passengers depends on the size of the fire load in the cabin of the aircraft, and it is determined by the characteristics of the materials. In case of fire, polymeric materials are flammable and emit large amounts of heat and smoke which contain poisonous gases that are the main causes of death. With the development of fire, the gas temperature changes in the volume of passenger compartment; therefore, it is necessary to set the dependence of the occurrence of death from heat.
\end{abstract}

Keywords: risk factors, safety of flights, safety parameter, statistics.

\section{Introduction}

Accident analysis of survivers shows that the main causes of fire death are attributed to the hazardous effects and consequences of panic attacks which usually

occur in such situations. Critical conditions for peoples lives can occur in just a few minutes. According to statistics, almost all aircraft accidents happen at the airports. 
The passengers are killed by the heat and toxicity of combustion products. This depends on the materials used in aircrafts' construction, especially for interior decoration.

In the design of an airplane cabin finishing materials are a wide variety of composite and polymeric materials. Therefore, it is necessary to determine the disposable (standby) time, since it depends on the size of the fire load in the cabin, and is a determining factor in the training of the crew and emergency services personnel in order to rescue passengers.

\section{An estimate of the fire load in the cabin of an aircraft}

The time available for the survival of the passengers depends on the size of the fire load in the cabin of an aircraft, and is determined by the characteristics of the materials. In the design of aircraft cabins, a variety of composite and polymer materials are widely used (Sakač 1989; Šestakov 1987).

According to (The structure...; TSO-C13f 1992; Rogačev 1989), the amount of composite and polymeric materials for narrow-body aircraft based on the total weight per passenger is up to $20 \mathrm{~kg} /$ person. and for a wide-body is up to $30 \mathrm{~kg} /$ person. A simple calculation shows that this is equivalent to about 4 tons of aviation fuel. In case of fire, polymeric materials are flammable and emit large amounts of heat and smoke which contain poisonous gases that are the main causes of death. The toxic gases considered here were CO, $\mathrm{CO}_{2}, \mathrm{HCL}, \mathrm{HCN}$ (Rogačev 1989). Data on toxicity is shown in Table 1 . Here the ratio of time after which a loss of consciousness appears to the total concentration of the gas is taken as a toxicity criterion (Volohina, Setinin 2001; Ejtingon et al. 1977; Alekseev et al. 1989).

Here: EC indicates concentration that causes adverse effects: $\mathrm{LC}_{50}-50 \%$ of people are killed in 5 minutes. Effects for various creatures: $h=$ man; $r=$ rat; $\mathrm{m}=$ mouse, $\mathrm{P}=$ monkey

Table 1 . Toxicity of various combustion products

\begin{tabular}{|c|c|c|c|c|}
\hline Formula & Gas & $\begin{array}{l}\mathrm{LC}_{50} \\
\text { impact to } \\
\text { humans } \\
\text { in } 5 \mathrm{~min} .\end{array}$ & $\begin{array}{c}\text { Impact to } \\
\text { humans } \\
\text { in } 30 \\
\text { min. }\end{array}$ & $\begin{array}{l}\text { Reference data } \\
\text { (type of animal } \\
\text { and the time of } \\
\text { impact) }\end{array}$ \\
\hline $\mathrm{CO}_{2}$ & $\begin{array}{l}\text { Carbon } \\
\text { dioxide }\end{array}$ & $>150,000$ & $>150,000$ & $\begin{array}{l}\mathrm{LC}(\mathrm{r}, 30)= \\
470,000\end{array}$ \\
\hline $\mathrm{HCl}$ & $\begin{array}{l}\text { Hydro- } \\
\text { gen chlo- } \\
\text { ride }\end{array}$ & 16,000 & 3,700 & $\begin{array}{l}\mathrm{LC}(\mathrm{r}, 5)= \\
40,989\end{array}$ \\
\hline $\mathrm{CO}$ & $\begin{array}{l}\text { Carbon } \\
\text { monox- } \\
\text { ide }\end{array}$ & - & 3,000 & $\begin{array}{l}\mathrm{LC}(\mathrm{r}, 30)= \\
4600 \\
\mathrm{LC}(\mathrm{h}, 30) 3000\end{array}$ \\
\hline $\mathrm{HCN}$ & $\begin{array}{l}\text { Prussic } \\
\text { acid }\end{array}$ & 280 & 135 & $\begin{array}{l}\mathrm{LC}(\mathrm{r}, 5)=570 \\
\mathrm{LC}(\mathrm{r}, 30)=110 \\
\mathrm{LC}(\mathrm{r}, 5)=503 \\
\mathrm{LC}(\mathrm{m}, 5)=323 \\
\mathrm{LC}(\mathrm{h}, 30)=135 \\
\mathrm{LC}(\mathrm{h}, 5)=280\end{array}$ \\
\hline
\end{tabular}

Table 2 shows the results of the quantitative determination of chemical compounds in the air in the passenger compartment during an experimental fire (flame retardant access unit) (DOT/FAA/AR-99/56 1999).

Table 2. Determination of chemical compounds in the air in the passenger compartment

\begin{tabular}{llll}
\hline \multirow{2}{*}{ Chemicals } & \multicolumn{3}{l}{ Time after the start of ignition } \\
\cline { 2 - 4 } & 2 minutes & 3 minutes & 4 minutes \\
\hline $\begin{array}{l}\text { Carbon monoxide } \\
\mathrm{CO}, \mathrm{mg} / \mathrm{m}^{3}\end{array}$ & 100000 & 120000 & 140000 \\
\hline $\begin{array}{l}\text { Carbon dioxide } \\
\mathrm{CO}_{2}, \% \text { vol. }\end{array}$ & 8.5 & 12.6 & 13.2 \\
\hline $\begin{array}{l}\text { Hydrogen cyanide } \\
\text { HCN }\end{array}$ & 300 & 400 & 500 \\
\hline $\begin{array}{l}\text { Hydrogen chloride } \\
\mathrm{HCl}, \mathrm{mg} / \mathrm{m}^{3}\end{array}$ & 8.0 & $\mathrm{HO}$ & 5.0 \\
\hline
\end{tabular}

This data allow us to compare the time necessary to evacuate people from a burning plane.

\section{Determination of available time}

We denote by the "time available" the time interval from the beginning of the fire till the onset of the critical parameters for the human body temperature in the passenger compartment. As already mentioned, it will be determined by the nature of the change in temperature and concentration of toxic substances. A comprehensive assessment of these factors will determine the coefficient of risk; the application of this procedure was defined in (A310... 2002):

$$
K_{0}=K_{T}+K_{X}
$$

where $K_{\mathrm{T}}, \mathrm{K}_{\mathrm{X}}$ indicate hazard ratios, taking into account the effect of temperature and toxic gases, respectively.

$\mathrm{K}_{\mathrm{T}}$ is the temperature parameter dose received by the human body as a result of staying in the air with temperature $\mathrm{T}$ for time $\mathrm{X}$.

$$
K_{T}=\tau_{T} / \tau_{C T}
$$

where:

$\tau_{T}$ - the residence time in medium temperature $\mathrm{T}, \mathrm{c}$; $\tau_{C T}$ - the onset of death at temperature $\mathrm{T}, \mathrm{c}$ (the time available).

With the development of fire, the temperature of the gas in the volume of the passenger compartment changes, so you need to set the dependence of the occurrence of death from heat. The approximation of the experimental data presented in (A320... 2005; Air Cruisers Company Engineering Document Number 2264) yielded the ratio:

$$
\tau_{C T}=1.23 \times 10^{5} \times e^{-0.0432(T-273)}-15 .
$$


Then:

$$
K_{T}=\int_{0}^{\tau}\left[1.23 \times 10^{5} \times e^{-0.0432(T-273)}-15\right]^{-1} d \tau .
$$

Parameter $\mathrm{K}_{\mathrm{X}}$ stands for "dose of poisonous substances" obtained by the human body during fire inside an aircraft.

Therefore:

$$
K_{X}=K_{C O}+K_{\mathrm{CO}_{2}}+K_{H C L}+K_{H C N}
$$

where $\mathrm{K}_{\mathrm{CO}}, \mathrm{K}_{\mathrm{CO}_{2}}, K_{\mathrm{HCL}}, K_{\mathrm{HCN}}$ indicate coefficients regarding the impact of carbon monoxide, carbon dioxide, hydrogen chloride and hydrogen cyanide, respectively.

In (The structure...; TSO-C13f 1992), the experimental data is presented for determining the time of onset of death in fire, depending on the concentration of oxides of these gases in the atmosphere of the cabin. This data can be expressed mathematically as:

$$
\begin{aligned}
& \tau_{C_{C O}}=571.9 e^{-3.35 C_{C O} ;} \\
& \tau_{C_{C_{2}}}=45001 C_{C O}^{-1} ; \\
& \tau_{C_{H C L}}=14.4 C_{H C L}^{-1} ; \\
& \tau_{C_{H C N}}=2.88 C_{H C N}^{-1} .
\end{aligned}
$$

Consequently, the coefficients, taking into account the impact of these gases, will be determined by the following expression:

$$
\begin{aligned}
& K_{C O}=\frac{1}{571.9} \int e^{3.35 C O(\tau)} d \tau ; \\
& K_{\mathrm{CO}_{2}}=\frac{1}{4500} \int_{0}^{\tau} C O_{2}(\tau) d \tau ; \\
& K_{H C L}=\frac{1}{14.4} \int_{0}^{\tau} C_{H C L}(\tau) d \tau ; \\
& K_{H C N}=\frac{1}{2.88} \int_{0}^{\tau} C_{H C N}(\tau) d \tau .
\end{aligned}
$$

where $\mathrm{C}_{\mathrm{CO}}, \mathrm{C}_{\mathrm{CO}_{2}}, C_{\mathrm{HCL}}, C_{\mathrm{HCN}}$ indicate carbon dioxide concentration, hydrogen chloride and hydrogen cyanide $\%$ (v) the onset of death due to exposure to $\mathrm{CO}, \mathrm{CO}_{2}, \mathrm{HCL}$ and $\mathrm{HCN}$, respectively. The final factor is defined as:

$$
\begin{aligned}
& K_{\mathrm{CO}_{2}}=\int_{0}^{\tau}\left[1.23 \times 10^{5} \times e^{-0.043\left(T_{(\tau)}-273\right)}-15\right]^{-1} d \tau+ \\
& 1.75 \times 10^{-3} \int_{0}^{\tau} e^{3.35 C_{C O}(\tau)} d \tau+2.22 \times 10^{-4} \int_{0}^{\tau} C O_{2}(\tau) d \tau+ \\
& 6.94^{-2} \int_{0}^{\tau} C_{H C L}(\tau) d \tau+4.386 \times 10^{-1} \int_{0}^{\tau} C_{H C N}(\tau) d \tau
\end{aligned}
$$

Thus, knowing the values of coefficients $K_{T}$ and $K_{x}$, we can determine the severity of the situation in the burning cabin, i.e. $\mathrm{K}_{0}$. In this case, the time available $\tau_{P}$, will be equal to the moment of achievement of coefficient $\mathrm{K}_{0}$ units (Bomštejna 1989).

\section{Determining the required time}

By "required time" in this case we mean the time necessary for the evacuation of passengers from a burning aircraft. This is a random variable that depends on many factors (A320... 2005). However, there are requirements defined by ICAO, according to which the evacuation in any scenario should not exceed 90 seconds. That is the norm set for designers and rescuers. Therefore, in international practice, evacuation opportunities are calculated for different aircraft fire scenarios. There is not standard procedure for such calculations. We use the technique described in (A310... 2002): by introducing restrictions recommended by ICAO.

This calculation is based on:

- Average distance of rows of chairs to the exit, $\mathrm{L}_{\mathrm{vid}}$;

- Distances from the chairs to the passage (between rows of chairs).

The Lvid impact on the likelihood of evacuation from an aircraft has been confirmed by many facts in practice. In order to control the escape probability for each aircraft type in accordance with ICAO requirements, it is not enough to only have one of these parameters, the Lvid. Total evacuation process time will depend on the method adopted for the process of evacuation, i.e. through the doors to the slide, through holes with a rope ladder, or simply move through the exit holes. In all cases, these methods need to be considered to set the ability to pass, i.e. the average speed of evacuation (for one person in each output separately).

If you comply with the conditions under which all the exits are exhausted (blocked or otherwise not functioning), the total evacuation time of passengers for a specific airplane type is calculated as follows:

$$
\begin{aligned}
& \mathrm{T}_{\text {ev.vid }}=\mathrm{t}_{\mathrm{d}}+\mathrm{t}_{\mathrm{l}}+\mathrm{t}_{\mathrm{r}}+\mathrm{t}_{\mathrm{p.tr}} / \mathrm{n}_{\text {izk.kop. }}+\mathrm{n}_{\mathrm{p} . t \mathrm{tr}} \times \\
& \mathrm{V}_{\text {ev.sag.p.tr. }}+\mathrm{l}_{\mathrm{np} . \mathrm{tr}}+\mathrm{n}_{\mathrm{r}} \times \mathrm{V}_{\text {ev.sag.r. }} \times \mathrm{l}_{\mathrm{nr} .}+\mathrm{n}_{\mathrm{v} . \mathrm{tr}} \times \\
& \mathrm{V}_{\text {ev.sag.v.tr. }} \times \mathrm{l}_{\text {nv.tr. }}+\mathrm{n}_{\mathrm{l}} \times \mathrm{V}_{\text {ev.sag.l. }} \times \mathrm{l}_{\mathrm{nl}} / \mathrm{n}_{\text {izk.kop, }}
\end{aligned}
$$

where:

$t_{d}$ - the time for preparation of the door for the evacuation process;

$t_{1}$ - the time for preparation of the hatch for the evacuation process;

$\mathrm{t}_{\mathrm{r}}$ - riffle preparation;

$t_{\text {p.tr }}$ - inflatable slide preparation;

$\mathrm{n}_{\mathrm{izk} . k o p}$ - the total number of exits;

$\mathrm{n}_{\text {p.tr }}$ - the number of exits which have inflatable slides;

$\mathrm{n}_{\mathrm{r}}$ - the number of exits which have riffles;

$\mathrm{n}_{\mathrm{v} . \mathrm{tr}}$ - the number of exits which have rope ladders; 
$\mathrm{n}_{1}$ - the number of exits which have escape hatches;

$l_{\text {np.tr }}$ - the number of evacuated people by inflatable slides;

$l_{n r}$ - the number of people evacuated by riffles;

$1_{\text {nv.tr }}$ - the number of people evacuated by rope ladders;

$1_{\mathrm{nl}}$ - the number of people evacuated by hatches;

$\mathrm{V}$ - the speed of evacuation during the defined time;

$\mathrm{V}_{\text {ev.p.tr. }}$ - the speed of evacuation by inflatable slides;

$\mathrm{V}_{\text {ev.r. }}$ - the speed of evacuation by riffles;

$\mathrm{V}_{\text {ev.v.tr. }}$ - the speed of evacuation by rope ladders;

$\mathrm{V}_{\text {ev.l }}$ - the speed of evacuation by hatches.

$\mathrm{V}_{\mathrm{vid}}$ - the average speed at which the transition from passenger seats to the exits takes place;

$\mathrm{L}_{\text {vid }}$ - the average distance between the rows of chairs and exits;

$t_{\text {ev.sag. }}$ - the preparation time for evacuation;

$\mathrm{V}_{\text {ev.sag }}$ - permeability of exits to escape;

The following values should be determined experimentally:

$\mathrm{V}_{\text {ev.sag }}$ - permeability of exits to escape;

$t_{\text {ev.sag. }}$ - the preparation time for evacuation.

By analogy, the time necessary to move to the exit is determined by:

$\mathrm{T}_{\text {sag }}=\mathrm{L}_{\text {vid }} / \mathrm{V}_{\text {vid }}$.

In order to comply with ICAO requirements, it is necessary to use an equation which determines an appropriate aircraft type for an evacuation:

$$
\mathrm{T}_{\text {ev.sag. }} \times 2 \mathrm{~K}=90 \mathrm{~s} \text {, }
$$

where $\mathrm{K}$ is the coefficient which includes passenger crowding at the exits in the direction of an airplane.

Figure 1 shows the evacuation planning process according to the number of people that pass through a given exit.

The scheme should be simple - no counter-flow with a steady output of each exit.

\section{Conclusions}

In this study, the coefficient of risk $\mathrm{K}_{0}$ was calculated using the method described for the case of burning of a block of chairs, considering the data from Table 2. As can be seen from the graph in Figure 1, the time to reach the coefficient $\mathrm{K}_{0}$ is 90 seconds.

Figure 2 shows the results of the experimental data (Volohina et al.).

As seen from Fig. 2, the coefficient of danger through the unit reaches 2.5 and 5 minutes, respectively, which is slightly longer than the yield calculations.

For this study, the arson was carried out with $300 \mathrm{ml}$ of alcohol spilled on the passenger seat. Animals (white rats) were killed within the period of 90-120 seconds after the start of the fire. However, the nature of the flow

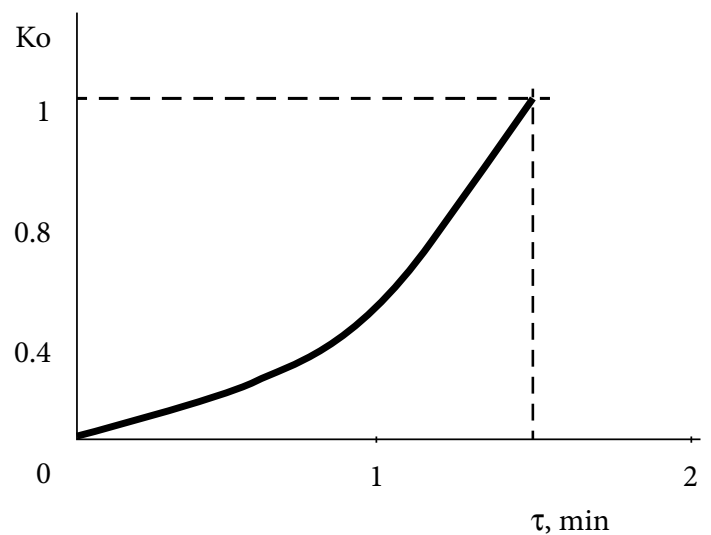

Fig. 1. Time to reach coefficient $\mathrm{K}_{0}$ is 90 seconds.

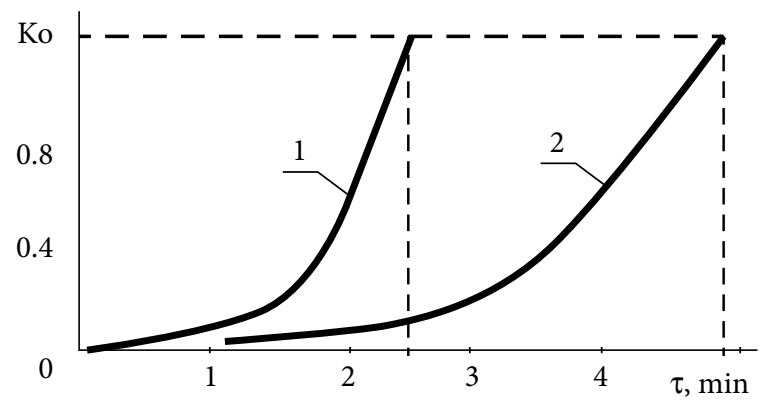

Fig. 2. Changing coefficient K0 when testing decorative finishing materials on a large-scale test bench: 1, IL-18, 2-IL-62.

curves and time confirmed the legitimacy of the coefficient of danger $\mathrm{K}_{0}$ application.

The coefficient was calculated for the evacuation of passengers through doors and escape hatches on one side from a Tu-154 aircraft in an accident with fire. Its value was 85 seconds, which corresponded to the ICAO standards and could be compared to the above-mentioned results of calculations and tests.

\section{References}

A310 airplane characteristics for airport planning. 2002. Reference: B.AC E 00A, Chapter 2.3.

A320 airplane characteristics for airport planning. 2005, Reference: D.AC ENV, Chapter 2.3.

Air Cruisers Company Engineering Document Number 2264, Qualification Test Report for IL-96 slide/rafts, Appendix AN, Coated Fabric Qual Test Report.

Alekseev, M. V.; Demidov, P. G.; Rojtman, M. Â.; TarasovAgalakov, N. A. 1971. Osnovy požarnoj bezopasnosti, Vysšaâ škola, učebnoe posobie dlâ VUZov,.1. R.Sakač, Bezopasnost' poletov učebnik dlâ VUZov GA pod redakciej, M.: Transport, 1989. 240 str.

Bomštejna, K. G. 1989. Sovety aviapassažiram. Soblûdenie pravil bezopasnosti poleta $i$ spaseniâ $v$ avarijnyh situaciâh, perevod s anglijskogo (Daniel A. Johnson "Just in case. A passenger's Guide to Airplane Safety and Survival"). Moskva, Transport.

Budnickij, G. A.; Mačalaba, N. N. 2001. O nekotoryh napravleniâh naučno-issledovatel'skih rabot instituta, VNII Polimernyh Volokon, Himičeskie Volokna, № 2, str. 4-13. 
DOT/FAA/AR-99/56 1999. Solis-State Thermochemistry of Flaming Combustion, Richard E. Lyon, Federal Aviation Administration, Airport and aircraft Safety Research and Development (AAR-422) William J. Hughes Technical Center Atlantic City International Airport, New Jersey.

Èjtingon, A. I.; Poddubnaâ, L. T.; Naumova, L. S.; Gribunova, G. P. 1977. Toksičnost' i sostav produktov goreniâ nekotoryh himičeskih i prirodnyh tkanej $i$ volokon, VNII Polimernyh Volokon, Himičeskie Volokna, № 4, str. 49-50.

Moryganov, A. P; Kolomejceva, È. A. 2001. Problemy i perspektivy ognezaŝitnoj otdelki tekstil'nyh materialov: Doklad, na seminare RSHTK, Progressivnaâ tehnologiâ zaklûčitel'noj otdelki tekstil'nyh materialov -garantiâ konkurentosposobnosti. Moskva.

Rogačev, A. A. 1989. Provedenie kačestvennogo i količestvennogo analiza toksičnyh gazov $i$ razrabotka rekomendacij po maksimal'no dopustimym koncentraciâm toksičnyh gazov: Tehničeskij otčet. GosNII GA. Moskva.

Sakač, R. 1989. Bezopasnost' poletov učebnik dlâ VUZov GA pod redakciej, M.: Transport, 240 str.

Šestakov, V. 1987. Inženerno-organizacionnoe obespečenie bezopasnosti poletov v Graždanskoj aviacii, M.: Transport, 170 str.

The structure of the chars forned during polymer combustion and is relation to flame retardancy, J. Kipling and Fengge Gao, Polymer Engineering Centre of Nottingham Trent University (United Kingdom).

TSO-C13f 1992. Life Preservers: Technical Standard Order, 24 August 1992.

Volohina, A. V.; Ŝetinin, A. M. 2001. Sozdanie vysokopročnyh, termo- i ognestojkih sintetičeskih volokon, VNII Polimernyh Volokon, Himičeskie Volokna, № 2, str. 14-21 